\title{
Studies on cocoa butter-replacer mixtures suitable for the local chocolate production
}

\author{
By M. Hassan El-Mallah and M.G. Megahed \\ National Research Centre, Fats and Oils Department, Dokki, Cairo, Egypt.
}

\begin{abstract}
RESUMEN
Estudios sobre mezclas manteca de cacao/sucedáneo adecuadas para la producción de chocolate local.

Se prepararon mezclas de manteca de cacao con diferentes sucedáneos añadidos en diferentes proporciones. Sus propiedades y particularmente el índice de grasa sólida, ayudaron mucho en la selección de la mezcla más adecuada para la producción de chocolate local. Se encontró que las mezclas con el 10\% o 15\% de Illexao en manteca de cacao, dieron los resultados más satisfactorios con respecto a la palatabilidad, dureza y consistencia.
\end{abstract}

PALABRAS-CLAVE: Chocolate - Indice de grasa sólida Mezcla manteca de cacao - sucedáneo.

\section{SUMMARY}

Studies on cocoa butter-replacer mixtures suitable for the local chocolate production.

Mixtures of cocoa butter with different replacers, added at different levels, were prepared. From their properties, and particularly solid fat index, helped much in selecting the more suitable mixture for local chocolate production. It was found that cocoa butter-lllexao mixtures, at levels $10 \%$ and $15 \%$ replacer, gave more satisfactory results with respect to mouthfeel, hardness and brittleness.

KEY-WORDS: Chocolate - Cocoa butter - replacer mixture - Solid fat index.

\section{INTRODUCTION}

Cocoa butter is essentially the natural fat of the cocoa bean, but definitions in some countries limit it to the natural fat obtained from well winnowed cocoa nib by hydraulic or expeller pressing (Minifie, 1980). Cocoa butter, which contributes $30-40 \%$ by weight to finished chocolate, provides the desired texture, mouthfeel, and flavor release properties. Variation in cocoa butter composition can result in unacceptable physical properties (Lees and Jackson, 1980; Chaiseri, and Dimick, 1989; Arruda and Dimick,
1989; Chaiseri and Dimick, 1995 a, b). In chocolate manufacturing, careful control of the solidification processes is quite important because it significantly influences both rheological properties of chocolate which determine the workability in the production processes and physical properties of end product such as gloss, snap, texture, heat resistance, fat bloom stability,... etc. The physical properties are related to polymorphism of cocoa butter, which comprises the major solid fat in chocolate (Chaseri and Dimick, 1995 b; Reddy et al., 1996; Malssen et al., 1996 a). At present, every one agrees that composition of cocoa butter influences its physical and chemical properties (Chaiseri and Dimick, 1989; Malssen et al., $1996_{\mathrm{a}, \mathrm{b}}$.

Cocoa butter, is an important and expensive ingredient in chocolate. Therefore, it is planned to prepare mixtures of cocoa butter with some substitutes at different weight ratios to select the most suitable one for chocolate production. Evaluation is mainly based on physical and chemical properties with emphasis on solid fat index (SFI). The substitutes that have selected include Cebes, Illexao and Nchox representing lauric and non-lauric acid substitutes.

\section{MATERIAL AND METHODS}

\section{Materials}

Cocoa butter and replacers, namely Cebes 30-80, Illexao 30-92 and Nchox 335 were supplied by ICA Factory of Egyptian Company for Foods, season 1996. These replacers are originally manufacturated in Malaysia by Aarhus Dliefabrik A/S and Premium Vegetable Oils SDN BHD Company. All solvents and chemicals are high purity grade of $\mathrm{BDH}$ (England) and MERCK (Germany).

\section{Methods}

Solid fat index (SFI) was determined according to IUPAC method (1972) using Nuclear Magnetic Resonance (NMR) Spectrometer Model/Bruker 
$\mathrm{PC} / \mathrm{C}$ (Minispec). SFI was measured at 5, 10, 15, 20, $25,30,35,40$ and $45^{\circ} \mathrm{C}$. Melting point (MP), refractive index (RI), iodine value (IV), saponification value (SV) and nonsaponifiable fraction (NSF) were determined according to the methods of A.O.C.S. (1985). All the results are the mean of two concordant and promising values.

\section{RESULTS AND DISCUSSION}

Melting point (MP), refractive index (RI), iodine value (IV), saponification value (SV) and nosaponifiable fraction (NSF) for natural cocoa butter and replacers as well as their mixtures are recorded in Table I. With reference to the MP, cocoa butter shows MP of $31.0^{\circ} \mathrm{C}$, however the replacers namely Cebes, Illexao and Nchox have MP of $35.5^{\circ} \mathrm{C}, 36.0^{\circ} \mathrm{C}$ and $36.0^{\circ} \mathrm{C}$, respectively. By using replacers at levels of $5 \%, 10 \%$ and $15 \%$ of the weight of cocoa butter, it was noticed that the MP of the mixtures markedly decreases. This decrease in MP can be due to the low MP of cocoa butter used as the main component of the mixtures (Minifie, 1980; Malssen et al., 1996 b). It is expected that this MP can be increased by pretreatment (tempering) during the processing and the production of chocolate. These changes can probably be due to the polymorphic forms of mixtures (Minifie, 1980; Lees and Jackson, 1980). Thus, increasing in MP is more desirable as quality criterion of the final product. It worthy to mention that low IV are exhibited by lauric acid replacers (Cebes and Nchox).

Table I

Chemical and physical properties of cocoa butter and its mixtures with different lauric and non-lauric replacers

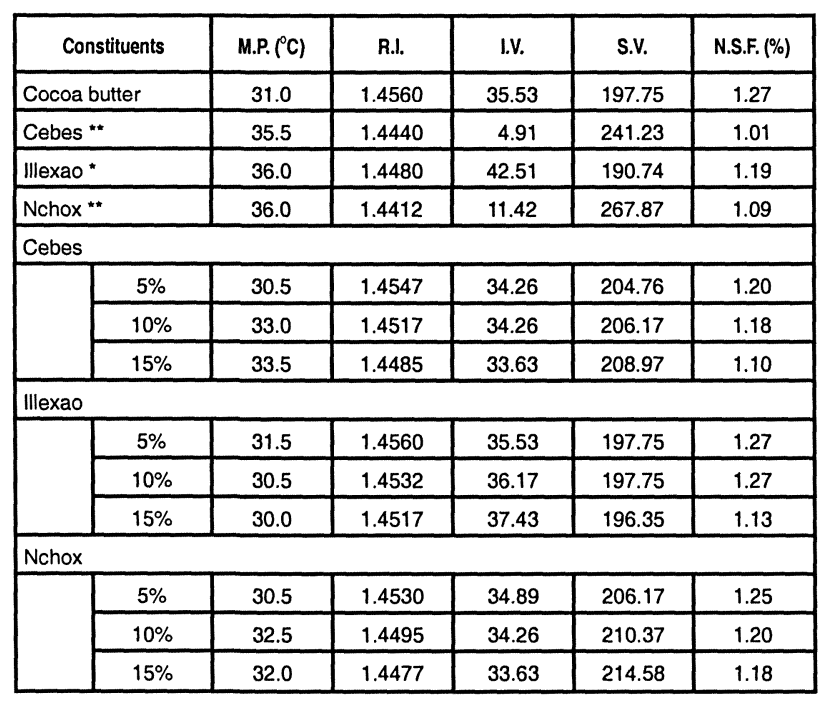

- Lauric replacer.

** Non-lauric replacer.
Solid fat index (SFI) for natural cocoa butter and replacers as well as their mixtures are recorded in Table II and are illustrated in Figures 1-4. In the frame of quality parameters, it is of interest to deal with the solid content at different temperatures. It is known that SFI of cocoa butter shows lower solid content $(28.7 \%$ and $2.05 \%)$ at range of $25-30^{\circ} \mathrm{C}$ and $0.95 \%$ at $35^{\circ} \mathrm{C}$. With reference to these changes in the three types of replacers (Cebes, Illexao and Nchox), it can be noticed that there are marked variations in SFI at the above mentioned temperature ranges (Minifie, 1980; Croklaan, 1980). Cebes exhibits SFI value of $94.93 \%, 90.95 \%$ and $60.43 \%$ at $20^{\circ} \mathrm{C}, 25^{\circ} \mathrm{C}$ and $30^{\circ} \mathrm{C}$, respectively whereas, Nchox gives nearly similar values at the same temperatures. However, Illexao give $69.77 \%$, $59.74 \%$ and $40.96 \%$ at $20^{\circ} \mathrm{C}, 25^{\circ} \mathrm{C}$ and $30^{\circ} \mathrm{C}$, respectively.

Dealing with the mixtures of Cebes replacers with cocoa butter at levels of $5 \%, 10 \%$ and $15 \%$, it can be seen that only $5 \%$ gives a high SFI at $20^{\circ} \mathrm{C}, 25^{\circ} \mathrm{C}$ and $30^{\circ} \mathrm{C}(61.02 \%, 21,73 \%$ and $6.11 \%)$. Meanwhile the $10 \%$ substitution of cocoa butter by Cebes gives $53.78 \%, 16.39 \%$ and $4.80 \%$ corresponding to $49.81 \%, 11.14 \%$ and $4.10 \%$ when substituting cocoa butter with $15 \%$ Cebes. It seems that the higher SFI can be obtained when substituting cocoa butter at a level of $5 \%$ of Cebes. When substituting cocoa butter with $5 \%, 10 \%$ and $15 \%$ of its weight with Nchox, there is a decrease in SFI particularly at $20^{\circ} \mathrm{C}$ at $25^{\circ} \mathrm{C}$, whereas the SFI is keept nearly constant at $30^{\circ} \mathrm{C}$. Thus, SFI at $20^{\circ} \mathrm{C}$ decreases to $60.84 \%$, $54.93 \%$ and $51.05 \%$ by substituting the cocoa butter with $5 \%, 10 \%$ and $15 \%$ of Nchox, respectively. On the other side, the SFI content at $25^{\circ} \mathrm{C}$ corresponds to $21.54 \%, 15.64 \%$ and $12.73 \%$. It is apparent that there is a gradual decrease of SFI at different temperatures when increasing the levels of replacers namely Cebes and Nchox. This may be due to the possibility that Cebes and Nchox are lauric acid replacers and therefore they affect the SFI in a similar manner when replacing cocoa butter (Croklaan, 1980; Sridhar et al., 1991).

Illexao, being non-lauric cocoa butter replacer, gives SFI approximating to that of cocoa butter when it substitutes the latter with different concentrations. Therefore, SFI is two-fold the value of cocoa butter at $30^{\circ} \mathrm{C}$. From these results, it can be noticed that Illexao is more suitable as a replacer for cocoa butter particularly at $10 \%$ and $15 \%$ levels.

With reference to the SFI that is more suitable for chocolate production in hot weather countries, it can be concluded that cocoa butter-Illexao mixtures are more suitable than mixtures with Cebes and Nchox, since the latter two substitutes tend to lower SFI at $20^{\circ} \mathrm{C}$ and $25^{\circ} \mathrm{C}$. 
Table II

Solid fat index (SFI) of cocoa butter and its mixtures with different lauric and non-lauric replacers

\begin{tabular}{|c|c|c|c|c|c|c|c|c|c|}
\hline Constituents & $5^{\circ} \mathrm{C}$ & $10^{\circ} \mathrm{C}$ & $15^{\circ} \mathrm{C}$ & $20^{\circ} \mathrm{C}$ & $25^{\circ} \mathrm{C}$ & $30^{\circ} \mathrm{C}$ & $35^{\circ} \mathrm{C}$ & $40^{\circ} \mathrm{C}$ & $45^{\circ} \mathrm{C}$ \\
\hline Cocoa butter & 95.24 & 92.79 & 84.11 & 69.26 & 28.70 & 2.05 & 0.95 & 0.00 & 0.00 \\
\hline Cebes ** & 99.42 & 99.34 & 96.88 & 94.93 & 90.95 & 60.43 & 1.75 & 0.00 & 0.00 \\
\hline Illexao * & 81.26 & 79.25 & 75.48 & 69.77 & 59.74 & 40.96 & 18.69 & 1.21 & 0.00 \\
\hline Nchox ** & 99.36 & 99.17 & 96.48 & 95.21 & 87.90 & 56.90 & 4.44 & 0.90 & 0.00 \\
\hline \multicolumn{10}{|l|}{ Cebes } \\
\hline $5 \%$ & 95.33 & 91.21 & 80.67 & 61.02 & 21.73 & 6.11 & 0.78 & 0.00 & 0.00 \\
\hline $10 \%$ & 95.72 & 92.24 & 83.46 & 53.78 & 16.39 & 4.80 & 1.34 & 0.00 & 0.00 \\
\hline $15 \%$ & 96.23 & 92.47 & 82.81 & 49.81 & 11.14 & 4.10 & 0.42 & 0.00 & 0.00 \\
\hline \multicolumn{10}{|l|}{ Illexao } \\
\hline $5 \%$ & 93.90 & 92.11 & 84.65 & 68.81 & 30.58 & 3.30 & 1.19 & 0.00 & 0.00 \\
\hline $10 \%$ & 92.98 & 91.69 & 82.71 & 69.78 & 33.16 & 4.46 & 1.02 & 0.00 & 0.00 \\
\hline $15 \%$ & 91.29 & 90.99 & 85.40 & 68.00 & 33.17 & 4.42 & 1.12 & 0.00 & 0.00 \\
\hline \multicolumn{10}{|l|}{ Nchox } \\
\hline $5 \%$ & 94.93 & 91.54 & 83.35 & 60.84 & 21.54 & 4.43 & 1.15 & 0.00 & 0.00 \\
\hline $10 \%$ & 95.37 & 91.72 & 82.50 & 54.93 & 15.64 & 4.50 & 0.92 & 0.00 & 0.00 \\
\hline $15 \%$ & 96.21 & 92.89 & 83.72 & 51.05 & 12.73 & 4.36 & 0.31 & 0.00 & 0.00 \\
\hline
\end{tabular}

* Lauric replacer.

** Non-lauric replacer.

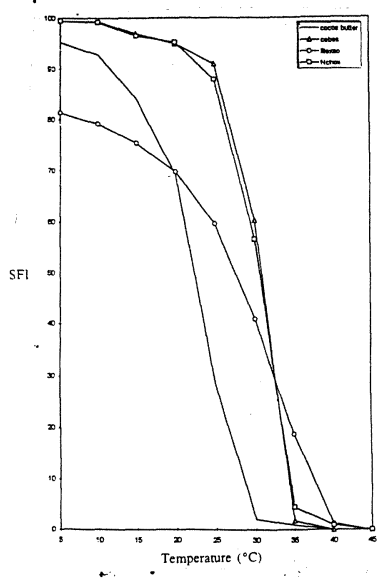

Figure 1

Solid fat index (SFI) of cocoa butter compared with some cocoa butter replacers at different temperatures.

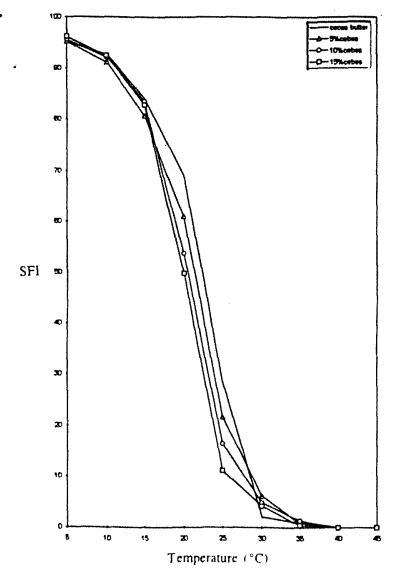

-Figure 2

Solid fat index (SFI) of cocoa butter as affected by addition of Cebes at different temperatures.

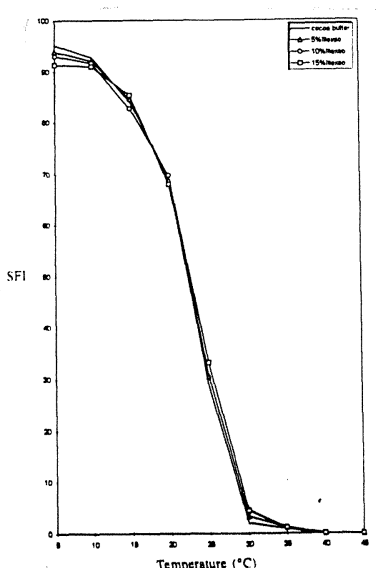

Figure 3

Solid fat index (SFI) of cocoa butter as affected by addition of Illexao at different temperatures

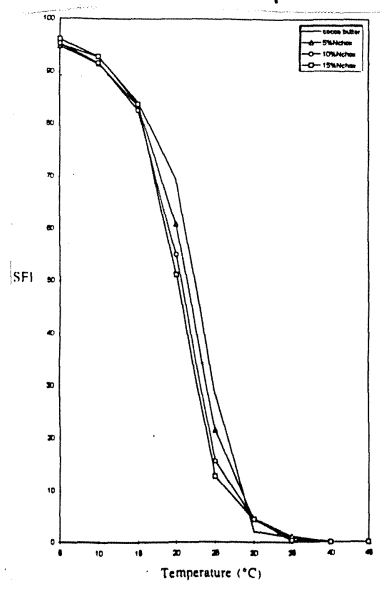

Figure 4

Solid fat index (SFI) of cocoa butter as affected by addition of Nchox at different temperatures. 
It is worthy to mention that high solid content acquires the chocolate product both hardness and brittleness at room temperature (Minifie, 1980; Lees and Jackson, 1980). On the other side, cocoa butter-Illexao mixtures show very lower SFI values at $35^{\circ} \mathrm{C}$ indicating that the total solids are nearly negligable at nearly the body temperature. It was reported that the absence of solids at body temperature, combined with the short melting range, indicates a pleasant mouthfeel (Croklaan, 1980).

Comparing SFI values at $20^{\circ} \mathrm{C}, 25^{\circ} \mathrm{C}$ and $35^{\circ} \mathrm{C}$ for cocoa butter-Illexao mixtures, it is observed that similar values are obtained. This confirms the view that cocoa butter-Illexao mixtures are more feasible in chocolate production in hot weather countries, moreover better mouthfeel and physical properties are obtained (Minifie, 1980; Lees and Jackson, 1980; Croklaan, 1980).

\section{REFERENCES}

1. A.O.C.S. (1985).- - The Offical and Tentative Methods of the American Oil Chemist's Society".- $3^{\text {rd }}$ Ed. Published by American Oil Chemist's Society. 508 South Sixth Street, Champaign, Illinois 61820, U.S.A.

2. Arruda, D.H. and Dimick, P.S. (1991).——Phospholipid composition of lipid seed crystal isolates from Ivory Coast cocoa butter".-J.A.O.C.S. 68, 385-390.

3. Chaiseri, S. and Dimick, P.S. (1989).- - Lipid and hardness characteristics of cocoa butters from different geographic regions".-J.A.O.C.S. 66, 17711776.

4. Chaiseri, S. and Dimick, P.S. (1995a).-«Dynamic crystallization of cocoa butter». I. Characterization of simple lipids in rapid- and Slow-nucleating cocoa butters and their seeds crystals.-J.A.O.C.S. 72 , 1491-1496.

5. Chaiseri, S. and Dimick, P.S. (1995b).-«Dynamic crystallization of cocoa butter". II. Morphological, thermal and chemical characteristics during crystal growth.-J.A.O.C.S. 72, 1497-1504.

6. Croklaan, B.V. (1980). - «Manual on Facts About Fats: Cocoa butter alternatives and their application".Croklaan B.V., P.O. Box 4, 1520 AA Wormerveer, Netherlands.

7. IUPAC (1972). - «Manual on Colloid and Surface Science".-International Union of Pure and Applied Chemistry, Butterworth, England.

8. Lees, R. and Jackson, E.B. (1980).- «Sugar Confectionary and Chocolate Manufacture".Published by: Leonard Hill a member of the Blackie Publishing Group. Bishopbriggs, Glasgow G64 2NZ, Great Britain.

9. Malssen, K.V.; Peschar, R. and Schenk, H. (1996a).«Real-time X-ray powder diffraction investigations on cocoa butter. I. Temperature-dependent crystallization behaviour".-J.A.O.C.S. 73, 1209-1215.

10. Malssen, K.V.; Peschar, R. and Schenk, H. (1996b).«Real-time $\mathrm{X}$-ray powder diffraction investigations on cocoa butter. II. The relationship between melting behaviour and composition of $\beta$-cocoa butter».J.A.O.C.S. 73, 1217-1223.

11. Minifie, B.W. (1980).- «Chocolate, Cocoa and Confectionary: Science and Technology" Second Edition. Published by: The AVI Publishing Company, INC., Westport, Connecticut, U.S.A.

12. Reddy, S.Y.; Full, N.; Dimick, P.S. and Zeigler, G.R. (1996). - «Tempering method for chocolate containing milk-fat fractions".-J.A.O.C.S. 73, 723-727.

13. Sridhar, R.; Lakshminarayana, G. and Kaimal, T.N.B. (1991).- - Modification of selected Indian vegetable fats into cocoa butter substitutes by lipase-catalyzed ester interchange».-J.A.O.C.S. 68, 726-730.

Recibido: Octubre 1997 Aceptado: Abril 1998 